\title{
Climatic Variability and Wet Season Rice (Oryza sativa L.) Production in North-West Bangladesh
}

\author{
J.C. Biswas ${ }^{1}$, M.B. Hossain ${ }^{2}$, A.K. Choudhury ${ }^{3}$, N. Kalra ${ }^{4}$ and M. Maniruzzaman ${ }^{2} *$ \\ ${ }^{1}$ Soil Science Division, ${ }^{2}$ Irrigation and Water Management Division, \\ Bangladesh Rice Research Institute, Gazipur 1701, Bangladesh \\ ${ }^{3}$ OFRD, Bangladesh Agricultural Research Institute, Gazipur, Bangladesh \\ ${ }^{4}$ Indian Agricultural Research Institute, New Delhi, India \\ *Corresponding author and Email: mzamaniwm@yahoo.com
}

Received: 15 January 2017

Accepted: 12 June 2017

\begin{abstract}
Climate change is influencing rice (Oryza sativa L.) production in some agro-ecological regions of Bangladesh. The impact of seasonal climatic variability on rainfed lowland rice (transplanted aman or T. Aman) yield in north-west Bangladesh was analyzed based on historic weather data from 1971 to 2010. Wet season maximum and minimum temperatures were increasing by 0.0174 and $0.0083^{\circ} \mathrm{C}_{\text {year }}{ }^{-}$ ${ }^{1}$, respectively. Sunshine hours for the same period have decreased by $0.0259-0.027 \mathrm{hr} \mathrm{year}^{-1}$. The representative concentration pathway (RCP) based projection showed increased maximum and minimum temperatures by $0.42-1.51$ and $0.79-1.34^{\circ} \mathrm{C}$, respectively in 2050 . T. Aman rice yield could be reduced by $0.17-0.37 \mathrm{t} \mathrm{ha}^{-1}$ if temperature rises by $1^{\circ} \mathrm{C}$. If sunshine hour decreases by $1 \mathrm{hr}$, yield reduction could be $0.20 \mathrm{t} \mathrm{ha}^{-1}$. Combined effect of increased minimum temperature and decreased sunshine hours will govern T. Aman rice yield in future.
\end{abstract}

Keywords: T. Aman rice yield, climatic variability, MAKESENS model.

\section{Introduction}

Bangladesh has attained self-sufficiency in rice (Oryza sativa L.) production despite high population pressure on land and other natural resources. This has mostly happened because of replacement of local varieties by the modern high yielding ones. Most countries consider domestic food grain production as an important factor for food price stabilization and food security. However, the success of food self sufficiency has been challenged by the population growth rate and by climate change vulnerability in Bangladesh (MoEF, 2009).

The demand for cereal foods, especially for rice, is expected to rise by $1.5 \%$ per annum for the next few decades. More food has to be produced from less cropped land areas in future (Timsina et al., 2016; BBS, 2016). Floods, cyclones, salinity and droughts are threatening food security of rural people. In coming years, these 
hazards are likely to aggravate (IPCC, 2013; Singh and Kalra, 2016). There are variable reports on rainfall amounts and its distribution (Rahman et al., 1997), but increase in temperature is likely to be $0.5-1.1^{\circ} \mathrm{C}$ per century (Mondal and Wasimi, 2004). Besides, increasing trend of mean maximum and minimum temperatures in some seasons and decreasing trend in some others climatic parameters during 1961-1990 were also observed (Rahman and Alam, 2003).

Climate change potentially invites disastrous consequences on rice and thus food security in Bangladesh. Rice crop occupies almost $80 \%$ of the total cropped area and accounts for more than $90 \%$ of total grain production. So, it dictates the necessity of assessing the effects of climate change on rice production in Bangladesh to ensure food security and economic growth in future. However, empirical investigations of the influence of climate change on crop agriculture in this country are limited (Rashid and Islam, 2007).

North-west part of Bangladesh is act as a food granary. Impacts of climatic variability and extreme events can impair food security in that region. For example, rice production could be reduced by $10-25 \%$ due to increase in temperature (Peng et al., 2004). Maniruzzaman and Biswas (2014) also reported 35\% reduction in wet season rice yield in Rajshahi region because of $1^{\circ} \mathrm{C}$ rise in maximum temperature, although spatial distribution of trends is not available. Climatic variability and its extreme events are concerns, and there is a need to evaluate climatic variability through growth and yield of rice. We need to know the appropriate management options to face the challenges of climate change. The knowledge gained would be effectively useful in understanding the agriresponse with the future climate change scenarios. Crop simulation tools are effective in this exercise, but the regression based approaches for understanding the dependence of growth and yield of crops with the historic weather data are also important. Regression models that use historical data on both climatic variables and yields are capable of providing accurate estimates of the changes in crop yield as a result of changes in climatic variables (Almaraz et al., 2008). However, such climatic variability is not reported with respect to crop yield variations. In the present study, interseasonal climatic variability was characterized through yield of T. Aman rice in North-west region of Bangladesh.

\section{Materials and Methods}

\subsection{Site description}

The research was carried out at Bangladesh Rice Research Institute, Gazipur during 2015-16. The north-west part of Bangladesh is situated at $23^{\circ} 47^{\prime} 45^{\prime \prime} \mathrm{N}$ to $25^{\circ} 46^{\prime} 34^{\prime \prime} \mathrm{N}$ latitude and $88^{\circ} 00^{\prime} 37^{\prime \prime}$ E to $89^{\circ} 49^{\prime} 11^{\prime \prime}$ E longitude, and covers an area of about $23,295 \mathrm{~km}^{2}$. It is composed of 4 districts those belong to Rajshahi region (Rajshahi, C. Nawabganj, Natore and Pabna), 4 districts under Rangpur region (Rangpur, Gaibandha, Kurigram and Lalmonirhat), 4 districts under Dinajpur region (Dinajpur, Nilphamari, Thakurgaon and Panchagarh) and 4 districts under Bogra region (Bogra, Joypurhat, Naogaon and Sirajganj). Total population of that area is 22.93 million of which more than $80 \%$ people live in rural areas those who mainly depend on agriculture. The density of population is about 860 people $\mathrm{km}^{-2}$. The study area is relatively dry humid in which annual average rainfall is $1,400-1,900 \mathrm{~mm}$. Almost $92.7 \%$ rainfall occurs during May to October. Inter-annual variability of nonmonsoonal rainfall is more than $50 \%$ (Shahid, 2008). Temperature ranges from $25^{\circ} \mathrm{C}$ to $40^{\circ} \mathrm{C}$ in the hottest season and $8^{\circ} \mathrm{C}$ to $25^{\circ} \mathrm{C}$ in the coolest one. About $90 \%$ land area is used for wet season rice cultivation. High yielding T. Aman rice varieties are dominant and shares almost $95 \%$ of total cultivated crop in wet season (BBS, 2013), which is threatened frequently by drought (Shahid, 2008). In the last 40 years, the area suffered by 8 droughts of major magnitude. Farmers use supplemental irrigation water to avoid drought effect wherever possible. 


\subsection{Data source and temporal trend analysis} Temperature, rainfall and sunshine duration data from 1971-2010 were obtained from four stations of Bangladesh Meteorological Department (BMD) and rice grain yield data were collected from Bangladesh Bureau of Agricultural Statistics for the whole north-west districts. The Mann-Kendall trend test (Mann, 1945) was used to detect trends in time series data and the test statistic distribution was explained by Kendall (1975) for testing nonlinear trends and turning points. The test assumes a monotonic trend and thus rejects the presence of any seasonal or other cycles in the data. The Mann-Kendall test is preferred when various stations are tested in a single study (Hirsch et al., 1991). Sen's slope estimator was used to determine the magnitude of change in the climatic parameter. The present study computed the confidence interval at $p=0.01$ and $p=0.05$. Representative Concentration Pathway (RCP) based projected data on temperature and rainfalls were used as average of Geophysical Fluid Dynamics Laboratory's Earth System Model (GFDL-ESM2M), Hadley Centre Global Environment Model version 2 Earth System Model (HadGEM2-ES), Institute Pierre Simon Laplace Low Resolution Climate System Model Version SA (IPSL-CMSA-LR), Model for Interdisciplinary Research on Climate version 5 (MIROC5) and Meteorological Research Institute Coupled Global Climate Model version 3 (MRI-CGCM3). The projected data of 2050 and 2100 were compared with average of 2001-2010 data, to judge the future projection with the present time normal trend. Four pathways: RCP8.5 (>8.5 $\mathrm{W} \mathrm{m}^{-2}$ by 2100$)$, RCP6 (6 W m${ }^{-2}$ after 2100), RCP4.5 (4.5 $\mathrm{W} \mathrm{m}^{-2}$ after 2100) and RCP2.6 (3 W m $\mathrm{W}^{-2}$ before 2100 and then declines) - the last is also referred to as RCP3-PD was considered in the present investigation.

Trend analyses for inter-annual and interseasonal, maximum, minimum and mean temperatures, rainfall and sunshine duration were carried out for those four locations. The descriptive statistics for yield of T. Aman rice and seasonal climatic elements were prepared. Growth rates of area and productivity of $T$. Aman rice were worked out as decadal basis by using the following formula:

Growth rate $=(\mathrm{X} 2-\mathrm{X} 1) /$ No. of years

Where,

$\mathrm{X} 2$ = calculated decadal year, area or yield

$\mathrm{X} 1$ = previous decadal year, area or yield

Annual and seasonal deviations of temperature, rainfall and sunshine hours and yield from the trend line were computed as follows (Maniruzzaman et al., 2017):

Percent deviation $(\%)=\{(\mathrm{Yi}-\overline{\mathrm{Y}}) / \overline{\mathrm{Y}}\} * 100$--- (2) where,

$\mathrm{Yi}=$ mean values of each climatic parameter or yield

$\mathrm{i}=$ number of years i.e. 1, 2, 3, ---------------- $n$

$\bar{Y}=$ normalized (or trend) value of each climatic parameters or yield

The combined effect of maximum and minimum temperatures, rainfall and sunshine hours on $T$. Aman rice yield was computed through multiple regression analyses. Several T. Aman varieties are grown in the test regions, but for the convenience of the climate change impact study average grain yield of all $T$. Aman varieties (as reported in BBS records) cultivated in the tested locations was considered as ideotypic response of variety. The predicted yield of T. Aman rice based on climatic parameters was computed as:

$\mathrm{Y}_{\text {T. Aman }}=\alpha_{1} \mathrm{~T}_{\max }+\alpha_{2} \mathrm{~T}_{\min }+\alpha_{3} \mathrm{RF}+\alpha_{4} \mathrm{SSH}+\mathrm{C}$---- (3) where,

$\mathrm{Y}_{T \text {. Aman }}=$ Yield of T. Aman rice in $\mathrm{t} \mathrm{ha}^{-1}$

$\mathrm{T}_{\max }=$ Average maximum temperature $\left({ }^{\circ} \mathrm{C}\right)$ from June to November

$\mathrm{T}_{\min }=$ Average minimum temperature $\left({ }^{\circ} \mathrm{C}\right)$ from June to November

$\mathrm{RF}=$ Total rainfall $(\mathrm{mm})$ from June to November $\mathrm{SSH}=$ Average sunshine hours (hrs) from June to November

$\mathrm{C}=$ Error term

$\mathrm{t}=$ Time (i.e. year)

$\alpha_{1}, \alpha_{2}, \alpha_{3}$ and $\alpha_{4}=$ Regression coefficients 


\section{Results and Discussion}

Table 1 shows descriptive statistics of $T$. Aman rice yield and seasonal climatic elements aggregated over the years from 1971 to 2010 . The average rice yield in wet season varied from 2.39 to $2.64 \mathrm{t} \mathrm{ha}^{-1}$ (having range of 1.35-3.78 t $\mathrm{ha}^{-1}$ ), which exposed to average maximum and minimum temperatures of $31.17-31.99^{\circ} \mathrm{C}$ and $23.67-24.21^{\circ} \mathrm{C}$, respectively. These temperature ranges were favorable for good T. Aman harvest. Though average rainfall $(1243-1813 \mathrm{~mm})$ was adequate for T. Aman rice, minimum $(637 \mathrm{~mm})$ and maximum $(3033 \mathrm{~mm})$ rainfall years were very much unfavorable for rice culture. This means T. Aman crop suffered from droughts in some years and floods in the other years resulting in yield losses. Sunshine hours varied consistently over the study areas with a range of 4.00 to $9.30 \mathrm{hrs}$ per day.

\subsection{T. Aman rice area and yield trends}

In general, T. Aman rice area showed mixed trend of increase or decrease, except for Rajshahi where continuous decreasing trend was observed but grain yield increased from 1981 to 2010 (Table 2) because of adoption of modern high yielding varieties, improved fertilizer and cultural managements and use of supplemental irrigation water. The share of $T$. Aman rice to total rice production is $38 \%$ in Bangladesh (BBS, 2013) and its contribution will be changed if temperature, rainfall and sunshine duration changes in future (IPCC, 2013).

\subsection{Annual and seasonal temperature patterns}

The Mann-Kendall trend test showed a significant increase in maximum and mean temperatures. Sen's slope showed increase in average annual maximum, minimum and mean temperatures by $0.001^{\circ} \mathrm{C}$ year $^{-1}, 0.016^{\circ} \mathrm{C}$ year $^{-1}$ $(\mathrm{Z}=3.20, \mathrm{p}<0.001)$ and $0.009^{\circ} \mathrm{C}$ year $^{-1}(\mathrm{Z}=$ $2.52, \mathrm{p}<0.05)$, respectively from 1971 to 2010 (Figure 1). However, wet seasonal maximum, minimum and mean temperatures increased by $0.0174^{\circ} \mathrm{C} \operatorname{year}^{-1}(\mathrm{Z}=3.85, \mathrm{p}<0.001), 0.0083^{\circ} \mathrm{C}$ year $^{-1}$ and $0.0129^{\circ} \mathrm{C} \operatorname{year}^{-1}(\mathrm{Z}=3.53, \mathrm{p}<0.001)$, respectively. Increasing trend of maximum temperature in wet season might be responsible for higher evapo-transpiration rate along with exposure of drought in study locations. Shahid (2010) also reported increased annual mean and minimum temperatures by $0.005^{\circ} \mathrm{C}$ year ${ }^{-1}$ and $0.013^{\circ} \mathrm{C}$ year $^{-1}$, respectively during 1958-2007. Hasan and Rahman (2013) showed that maximum temperature was increasing by $0.005^{\circ} \mathrm{C}$ year $^{-1}$, with maximum increase in November $\quad\left(0.02^{\circ} \mathrm{C} \quad\right.$ year $\left.^{-1}\right) . \quad$ Minimum temperature was also increasing by $0.014^{\circ} \mathrm{C}$ year ${ }^{-1}$, but the highest increase $\left(0.027^{\circ} \mathrm{C}_{\text {year }}{ }^{-1}\right)$ was observed in February. The analysis was done on yearly basis, whereas for making simple presentation we have presented the decadal trend in Table 2.

In 2050 wet season, maximum temperature in the study region is likely to increase by 0.42 to $1.51^{\circ} \mathrm{C}$ compared to $2001-2010$ depending on RCPs but it would be 0.79 to $1.57^{\circ} \mathrm{C}$ for minimum temperature and 0.61 to $1.21^{\circ} \mathrm{C}$ for mean temperature (Table 3 ). At the end of this century, maximum temperature is likely to increase by 0.25 to $3.58^{\circ} \mathrm{C}$ and minimum by 0.41 to $3.75^{\circ} \mathrm{C}$ with an average of 0.36 to $3.66^{\circ} \mathrm{C}$ depending on RCPs (Table 3). In both the projected years, increase in minimum temperature is rapid compared to maximum temperature. Increase in minimum temperature is more alarming for crop production due to increased respiratory loss and greater water demand. Agarwala et al. (2003) reported that annual temperature will be increasing by $1.0^{\circ} \mathrm{C}$, $1.4^{\circ} \mathrm{C}$ and $2.4^{\circ} \mathrm{C}$, respectively during 2030,2050 and 2100 in Bangladesh; whereas wet season temperature will be increasing by $0.8^{\circ} \mathrm{C}, 1.1^{\circ} \mathrm{C}$ and $1.9^{\circ} \mathrm{C}$, respectively for the same years. Our findings are almost similar to Agarwala et al. (2003). Based on data from 1961 to 1990, Karmakar and Shrestha (2000) reported that the projected annual maximum temperature in Bangladesh will increase by 0.4 and $0.73^{\circ} \mathrm{C}$ in 2050 and 2100, respectively, which is also similar but lower to our findings. 
Table 1. Descriptive statistics of historic T. Aman rice yield and some weather variables (1971-2010) in north-west region of Bangladesh

\begin{tabular}{|c|c|c|c|c|c|c|c|c|c|c|c|c|c|c|c|c|c|c|c|c|}
\hline \multirow[t]{3}{*}{ Statistics } & \multicolumn{20}{|c|}{ Variables } \\
\hline & \multicolumn{4}{|c|}{ Yield $\left(\mathrm{t} \mathrm{ha}^{-1}\right)$} & \multicolumn{4}{|c|}{ Maximum temperature $\left({ }^{\circ} \mathrm{C}\right)$} & \multicolumn{4}{|c|}{ Minimum temperature $\left({ }^{\circ} \mathrm{C}\right)$} & \multicolumn{4}{|c|}{ Rainfall (mm) } & \multicolumn{4}{|c|}{ Sunshine hours } \\
\hline & $\overline{\mathrm{Raj}}$ & Din & Rang & Bog. & Raj. & Din. & Rang. & Bog. & Raj. & Din. & Rang. & Bog. & Raj. & Din. & Rang. & Bog. & Raj. & Din. & Rang. & Bog. \\
\hline Mean & 2.41 & 2.39 & 2.57 & 2.64 & 31.99 & 31.35 & 31.17 & 31.76 & 24.08 & 23.67 & 23.68 & 24.21 & 1243 & 1646 & 1813 & 1458 & 6.03 & 6.93 & 5.86 & 5.87 \\
\hline Std. dev. $( \pm)$ & 0.74 & 0.50 & 0.43 & 0.53 & 0.45 & 0.55 & 0.55 & 0.54 & 0.45 & 0.39 & 0.50 & 0.39 & 289 & 458 & 447 & 358 & 0.46 & 1.10 & 0.56 & 0.60 \\
\hline Maximum & 3.78 & 3.73 & 3.37 & 3.76 & 33.5 & 33.42 & 33.48 & 32.78 & 25.38 & 24.78 & 24.62 & 25.25 & 1869 & 2847 & 3033 & 2325 & 7.13 & 9.30 & 7.35 & 7.28 \\
\hline Minimum & 1.35 & 1.63 & 1.80 & 1.59 & 30.87 & 30.43 & 30.40 & 30.45 & 23.22 & 22.70 & 21.85 & 23.27 & 637 & 901 & 967 & 758 & 4.88 & 4.00 & 5.02 & 4.87 \\
\hline Skewness & 0.34 & 0.88 & 0.17 & 0.01 & -0.15 & 1.32 & 2.01 & -0.25 & 0.23 & 0.16 & -1.26 & 0.30 & -0.10 & 0.76 & 0.57 & 0.45 & 0.18 & -0.30 & 0.81 & 0.49 \\
\hline Kurtosis & -1.17 & 0.49 & -1.04 & -1.06 & 1.32 & 4.05 & 7.14 & -0.01 & 0.50 & 1.27 & 3.44 & 0.31 & -0.35 & 0.50 & 0.88 & -0.44 & 0.98 & 1.25 & 0.70 & -0.44 \\
\hline
\end{tabular}

Raj. = Rajshahi, C. Nawabganj, Natore and Pabna, Din. = Dinajpur, Nilphamari, Thakurgaon and Panchagarh, Rang. = Rangpur, Gaibandha, Kurigram and Lalmonirhat, Bog. = Bogra, Joypurhat, Naogaon and Sirajganj

Table 2. Decadal changes in cultivated area of T. Aman rice and yield in north-west region of Bangladesh

\begin{tabular}{|c|c|c|c|c|c|c|c|c|c|c|c|c|c|c|c|c|}
\hline \multirow[t]{2}{*}{ Year } & \multicolumn{4}{|c|}{ Rajshahi region } & \multicolumn{4}{|c|}{ Dinajpur region } & \multicolumn{4}{|c|}{ Rangpur region } & \multicolumn{4}{|c|}{ Bogra region } \\
\hline & Area (ha) & $\begin{array}{l}\text { GR } \\
\mathrm{yr}^{-1}\end{array}$ & $\begin{array}{l}\text { Yield } \\
\left(\mathrm{t} \mathrm{ha}^{-1}\right)^{*}\end{array}$ & $\begin{array}{l}\text { GR } \\
\mathrm{yr}^{-1}\end{array}$ & Area (ha) & $\begin{array}{l}\text { GR } \\
\mathrm{yr}^{-1}\end{array}$ & $\begin{array}{l}\text { Yield } \\
\left(\mathrm{t} \mathrm{ha}^{-1}\right)\end{array}$ & $\begin{array}{l}\text { GR } \\
\mathrm{yr}^{-1}\end{array}$ & $\begin{array}{l}\text { Area } \\
\text { (ha) }\end{array}$ & $\begin{array}{l}\text { GR } \\
\mathrm{yr}^{-1}\end{array}$ & $\begin{array}{l}\text { Yield } \\
\left(\mathrm{t} \mathrm{ha}^{-1}\right)\end{array}$ & $\begin{array}{l}\text { GR } \\
\mathrm{yr}^{-1}\end{array}$ & Area (ha) $\mathrm{G}$ & R & $\begin{array}{l}\text { Yield } \\
\left(\mathrm{t} \mathrm{ha}^{-1}\right)\end{array}$ & $\begin{array}{l}\text { GR } \\
\mathrm{yr}^{-1}\end{array}$ \\
\hline $1970-71$ & 462591 & - & 1.896 & - & 361660 & - & 1.889 & - & 520972 & - & 2.107 & - & 266478 & - & 1.973 & - \\
\hline $1979-80$ & 423324 & -4363 & 1.672 & -0.025 & 344387 & -1919 & 1.887 & 0.000 & 543154 & 2465 & 2.203 & 0.011 & 256158 & -1147 & 2.044 & 0.008 \\
\hline $1989-90$ & 408269 & -1506 & 2.482 & 0.081 & 438425 & 9404 & 2.611 & 0.072 & 590684 & 4753 & 2.719 & 0.052 & 235243 & -2092 & 2.925 & 0.088 \\
\hline 1999-00 & 392980 & -1529 & 3.055 & 0.057 & 418976 & -1945 & 2.256 & -0.036 & 580972 & -971 & 3.050 & 0.033 & 234777 & -47 & 2.819 & -0.011 \\
\hline 2009-10 & 388760 & -422 & 3.783 & 0.073 & 443973 & 2500 & 3.735 & 0.148 & 546369 & -3460 & 3.295 & 0.025 & 246513 & 1147 & 3.199 & 0.038 \\
\hline
\end{tabular}

* Paddy (Adopted from BBS, 1973, 1982, 1991, 2001 and 2011), GR= Growth rate 
Table 3. Projections for changes in T. Aman seasonal temperature and rainfall in north-west region of Bangladesh based on 2001-2010

\begin{tabular}{lcrrrl}
\hline \multirow{2}{*}{ Year } & RCPs & \multicolumn{3}{c}{ Temperature change $\left({ }^{\circ} \mathrm{C}\right)$} & \multicolumn{1}{c}{$\begin{array}{c}\text { Average rainfall } \\
\text { change }(\%)\end{array}$} \\
\cline { 3 - 5 } & & Tmax & Tmin & Tmean & \multicolumn{1}{c}{$30.03(8.9)$} \\
& RCP2.6 & $0.62(1.6)$ & $0.79(1.8)$ & $0.72(1.7)$ & $28.28(12.5)$ \\
& RCP4.5 & $1.51(1.4)$ & $1.34(2.3)$ & $1.20(1.8)$ & $22.63(7.8)$ \\
& RCP6.0 & $0.42(1.8)$ & $0.81(1.7)$ & $0.61(1.7)$ & $17.82(10.2)$ \\
& RCP8.5 & $0.98(2.1)$ & $1.57(2.3)$ & $1.21(2.2)$ & $44.78(8.8)$ \\
& RCP2.6 & $0.25(1.8)$ & $0.41(2.6)$ & $0.36(2.3)$ & $49.71(9.7)$ \\
& RCP4.5 & $1.33(2.2)$ & $1.75(1.9)$ & $1.56(2.0)$ & $10.10(6.8)$ \\
& RCP6.0 & $2.03(2.3)$ & $2.12(2.5)$ & $2.02(2.4)$ & $35.58(10.5)$ \\
\hline
\end{tabular}

Figures in the parentheses indicate standard deviation $( \pm)$.

Shahid (2011) projected that mean temperature is likely to increase by $0.8^{\circ} \mathrm{C}$ in $2025,1.4^{\circ} \mathrm{C}$ in $2050,1.9^{\circ} \mathrm{C}$ in 2075 and $2.4^{\circ} \mathrm{C}$ in 2100 . In 2100 , the minimum increase in mean temperature would be about $1.4^{\circ} \mathrm{C}$ in July that is closer to our findings. Our investigation reveals that increase in temperature in north-west region of Bangladesh would be lower than projected by others (Karmakar and Shrestha, 2000; Agarwala et al., 2003; Shahid, 2011; IPCC, 2013). Most of these reports are based on global climate models (General Circulation Models) outputs, which usually require accurate regional calibration and vary depending on models. Historically, mean annual temperature was at around $25.17^{\circ} \mathrm{C}$ and average minimum and maximum temperatures were $19.98^{\circ} \mathrm{C}$ and $30.36^{\circ} \mathrm{C}$, respectively. Similarly, mean annual, minimum and maximum temperatures during wet season were $27.74^{\circ} \mathrm{C}$, $23.91^{\circ} \mathrm{C}$ and $31.57^{\circ} \mathrm{C}$, respectively. Mean annual temperature in Rajshahi region was about $25.75^{\circ} \mathrm{C}$ and mean minimum and maximum temperatures were $20.83^{\circ} \mathrm{C}$ and $30.87^{\circ} \mathrm{C}$, respectively. High temperature (as high as $45.1^{\circ} \mathrm{C}$ ) is generally observed in April and May and the lowest $\left(3.4^{\circ} \mathrm{C}\right)$ in January.

Decrease in rice yield due to higher temperature is mainly associated with reduced growth duration of a crop (Shahid, 2011). The other reasons could be greater respiration loss and increased evaporative demand.

\subsection{Annual and seasonal rainfall patterns}

Average annual rainfall of the study region increased by $1.38 \mathrm{~mm} \mathrm{year}^{-1}$ and wet season rainfall increased by about $0.7266 \mathrm{~mm} \mathrm{year}^{-1}$ (Figure 2). The average wet season rainfall in north-western region of Bangladesh varied from 1243 to $1813 \mathrm{~mm}$ (Table 1), which is sufficient if it is uniformly distributed in wet season. But, in some years it is as low as $637 \mathrm{~mm}$ and distribution is not also uniform. Long-term (1971-2010) rainfall data revealed that both annual and wet seasonal rainfall was slightly increasing in trend (Figure 2). Supplemental irrigation was essential in those low rainfall years for successful T. Aman rice production.

Hussain (2011) reported increased rainfall during March through November in both 2050 and 2070 A.D. Shah et al. (2013) reported changing precipitation patterns. Our findings also revealed very much fluctuating rainfall patterns. Rainfall in wet season is likely to be increased and thus might create flooding situation in wet season, which may influence in $T$. Aman rice production (Table 3).

\subsection{Annual and season-wise sunshine hour}

Annual average sunshine hours in study locations were decreasing $(Z=-6.05, \mathrm{p}<0.001)$. Sen's slope estimator showed annual sunshine hour decrease of $0.027 \mathrm{hrs}^{\text {year }}{ }^{-1}$ from 1971 to 2010; but wet season sunshine hours decreased by $0.0259 \mathrm{hrs}$ year $^{-1}(\mathrm{Z}=-4.82, \mathrm{p}<0.001)$ for the 
same period (Figure 3). Sunshine hour is decreasing at a continuous rate per year, which is primarily because of increased suspended particulate matter (SPM) and aerosols concentration in the atmosphere. Our findings are in agreement with the works in South Asian Region under Atmospheric Brown Cloud Project of UNEP (Kalra et al., 2006).. Shah et al. (2013) also reported decreased annual sunshine hours by about $5.3 \%$ per decade. These indicate that there would be reduction in $T$. Aman rice yield because of reduced sunshine hours. In general, sufficient and quality sunlight is needed for increased production of tillers and panicles (Shi et al., 2002). So, radiation-use efficient varieties are to be developed for the farmers in future.

\subsection{Inter-seasonal climatic variability effects on T. Aman rice yield}

Average maximum temperature of study regions varied from 31.17 to $31.99^{\circ} \mathrm{C}$ and average rice yield varied from 2.39 to $2.64 \mathrm{t} \mathrm{ha}^{-1}$ (Table 1). If maximum temperature increases by $1^{\circ} \mathrm{C}, T$. Aman rice yield is likely to decrease by $10.94 \%$ i.e. about $0.27 \mathrm{t} \mathrm{ha}^{-1}$ (Figure $4 \mathrm{a}$ ). Since northwestern part of the country is relatively hotter during wet season, even relatively lower increase in maximum temperature would cause noticeable yield reduction because of increased evapotranspiration, increased respiratory activities and thus reduced net assimilates available for growth and reduced growth duration of $T$. Aman rice. On the contrary, average minimum temperature in the study regions varied from 23.673 to $24.21^{\circ} \mathrm{C}$ (Table 1). Wet season minimum temperature was in increasing trend (Figure 1). If minimum temperature increases by about $1^{\circ} \mathrm{C}, T$. Aman rice yield would be reduced by $6.72 \%$, i.e. about $0.17 \mathrm{t} \mathrm{ha}^{-1}$ (Figure $4 \mathrm{~b}$ ).

Mean temperature during wet season was increasing in trend (Figure 1). If mean temperature increases by about $1^{\circ} \mathrm{C}, T$. Aman rice yield reduction would be $14.83 \%$ i.e. about $0.37 \mathrm{t}$ $\mathrm{ha}^{-1}$ (Figure 4c), which is very much similar to the findings of Mabe et al., 2014. Under elevated temperature of $2^{\circ} \mathrm{C}$ and $4^{\circ} \mathrm{C}$, the grain yield was
13.3 and 23 percent less than ambient temperature (Rani and Maragatham, 2013). The country is predicted to experience an increase in average temperature of $1.4^{\circ} \mathrm{C}$ by 2050 and consequently, the rice production is likely to decline by $8-17 \%$ (IPCC, 2007). According to IPCC estimates, increasing temperature and changing rainfall pattern along with flooding, drought and salinity, Bangladesh might face a decline in crop production by 2050 . Against 1990 base year, the predicted declines were $8 \%$ in rice and $32 \%$ in wheat (MoEF, 2009).

Seasonal rainfall was slightly increasing in north-western part of Bangladesh (Figure 2). Effect of seasonal total rainfall on T. Aman rice yield was insignificant (Figure 4d). Water demand was fulfilled through supplemental irrigation in most cases. So, decrease in rainfall has not yet been created any yield loss in northwest region of the country.

Seasonal sunshine hours were in decreasing trend (Figure 3). If sunshine hour decreases by 1 hour, T. Aman rice yield is likely to decrease by $8.17 \%$ i.e. about $0.20 \mathrm{t} \mathrm{ha}^{-1}$ (Figure $4 \mathrm{e}$ ). Shah et al. (2013) reported $3.4 \%$ reduced wet season sunshine hour per decade indicating its negative effect on rice yield. They also reported reduced grain yield and yield components with the reduction of solar radiation. Combined effect of average maximum and minimum temperatures and sunshine hours on rice yield was computed through multiple regression analyses. Predicted rice yield was in close agreement with the observed yield (Figure 5). Our analyses indicate that increase in temperature and reduction in sunshine hours would play an important role for reduction of $T$. Aman rice yield in future. The model has an F-value of 12.65 with a p-value of 0.000 indicating that overall model result was statistically significant at $1 \%$ level of probability. About $25 \%$ of the variations in T. Aman rice yields are explained by climatic variables. The tvalue of average maximum temperature was 4.27 and for average sunshine hours was -4.88 , which were statistically significant at $1 \%$ level of probability. 

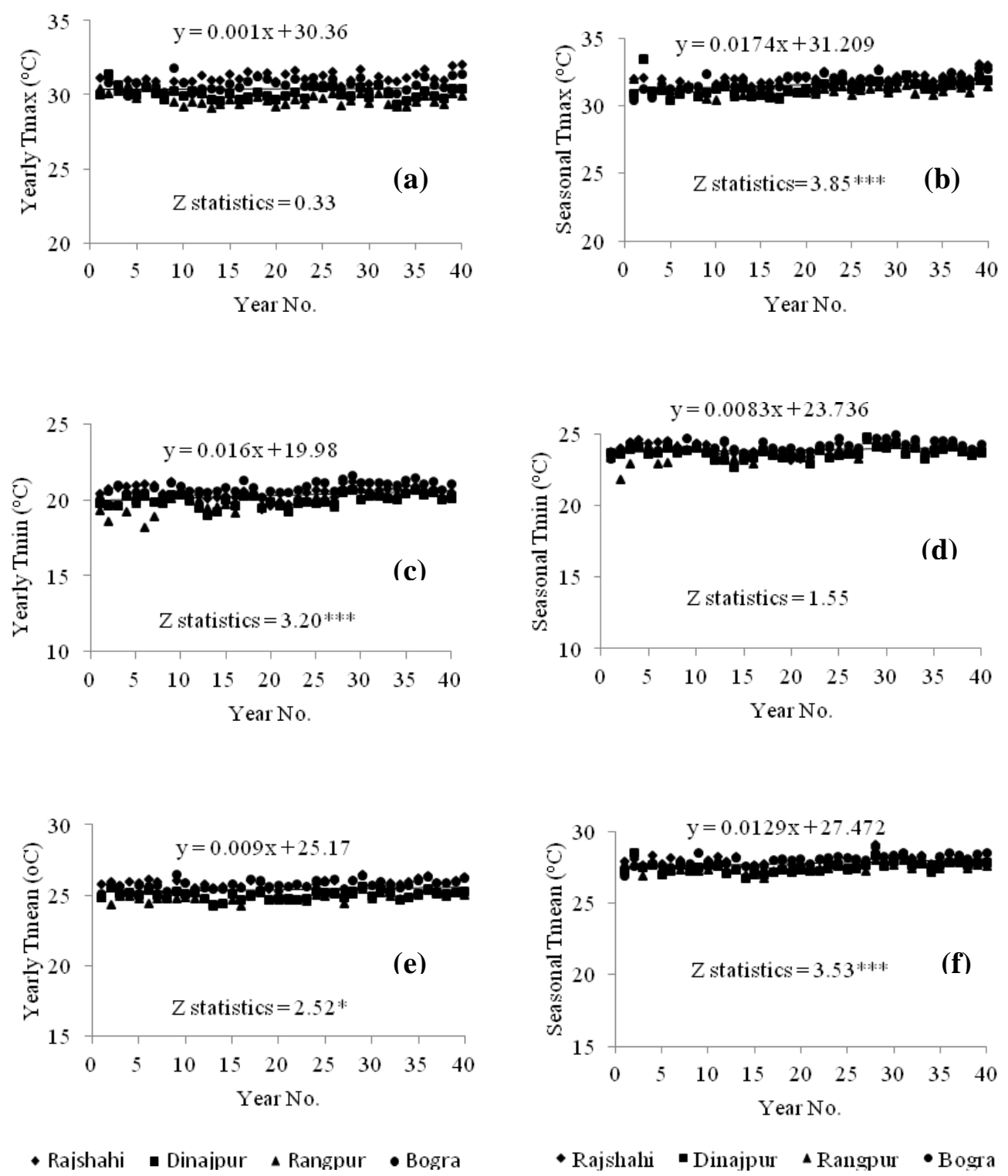

Figure. 1. Observed trends in average yearly and T. Aman seasonal temperature: (a \& b)-maximum, (c \& d)- minimum and (e \& f)- mean in north-west region of Bangladesh. Year no. starts from $1971(* \mathrm{p}<0.05 ; * * \mathrm{p}<0.01 ; * * * \mathrm{p}<0.001)$ 

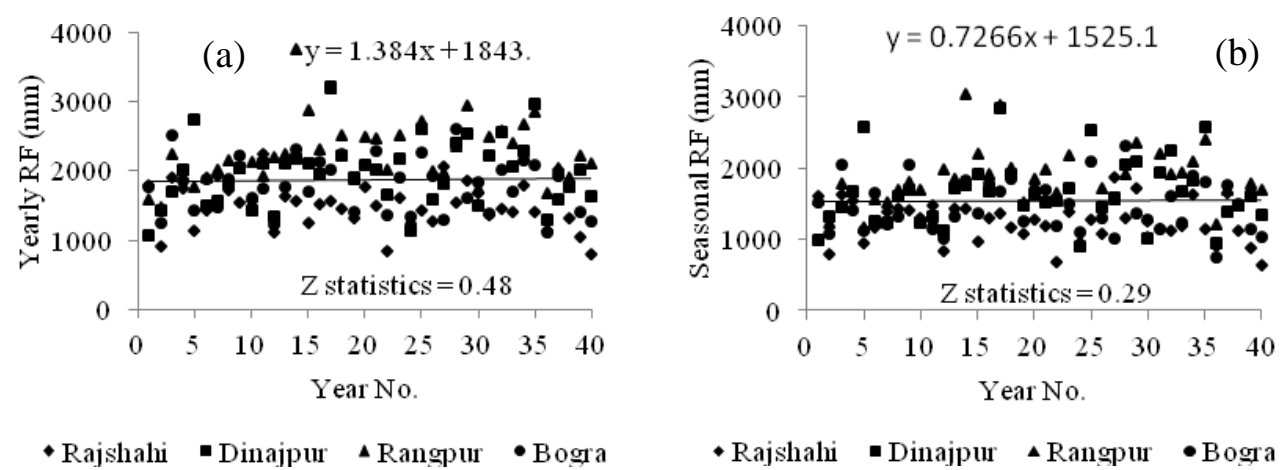

Figure 2. Observed trends in rainfall: (a)- yearly and (b)- T. Aman season in north-west region of Bangladesh. Year no. starts from 1971
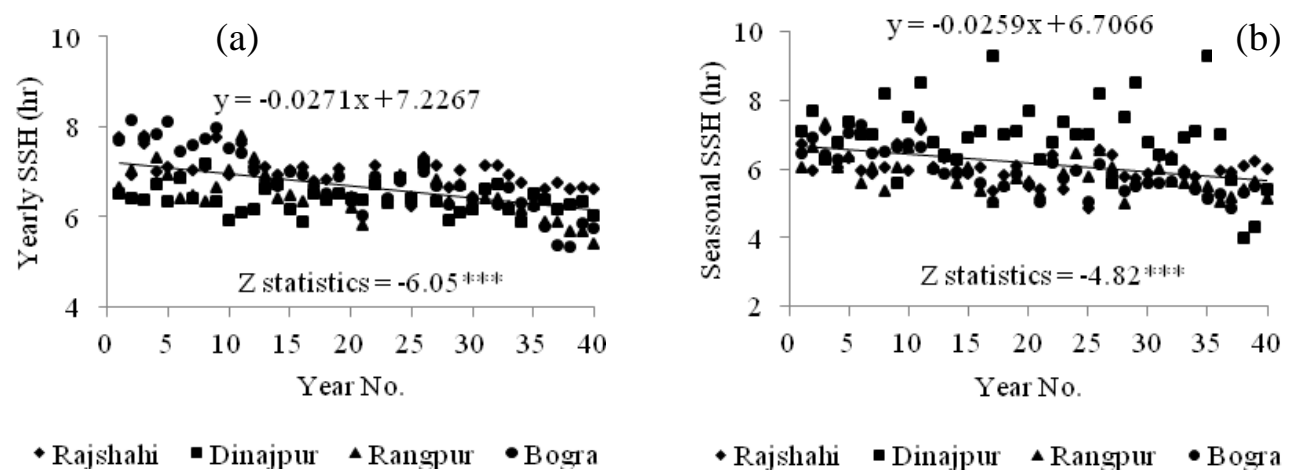

Figure 3. Observed trends in average sunshine hours: (a)- yearly and (b)- T. Aman season in northwest region of Bangladesh. Year no. starts from $1971(* \mathrm{p}<0.05 ; * * \mathrm{p}<0.01 ; * * * \mathrm{p}<0.001)$ 

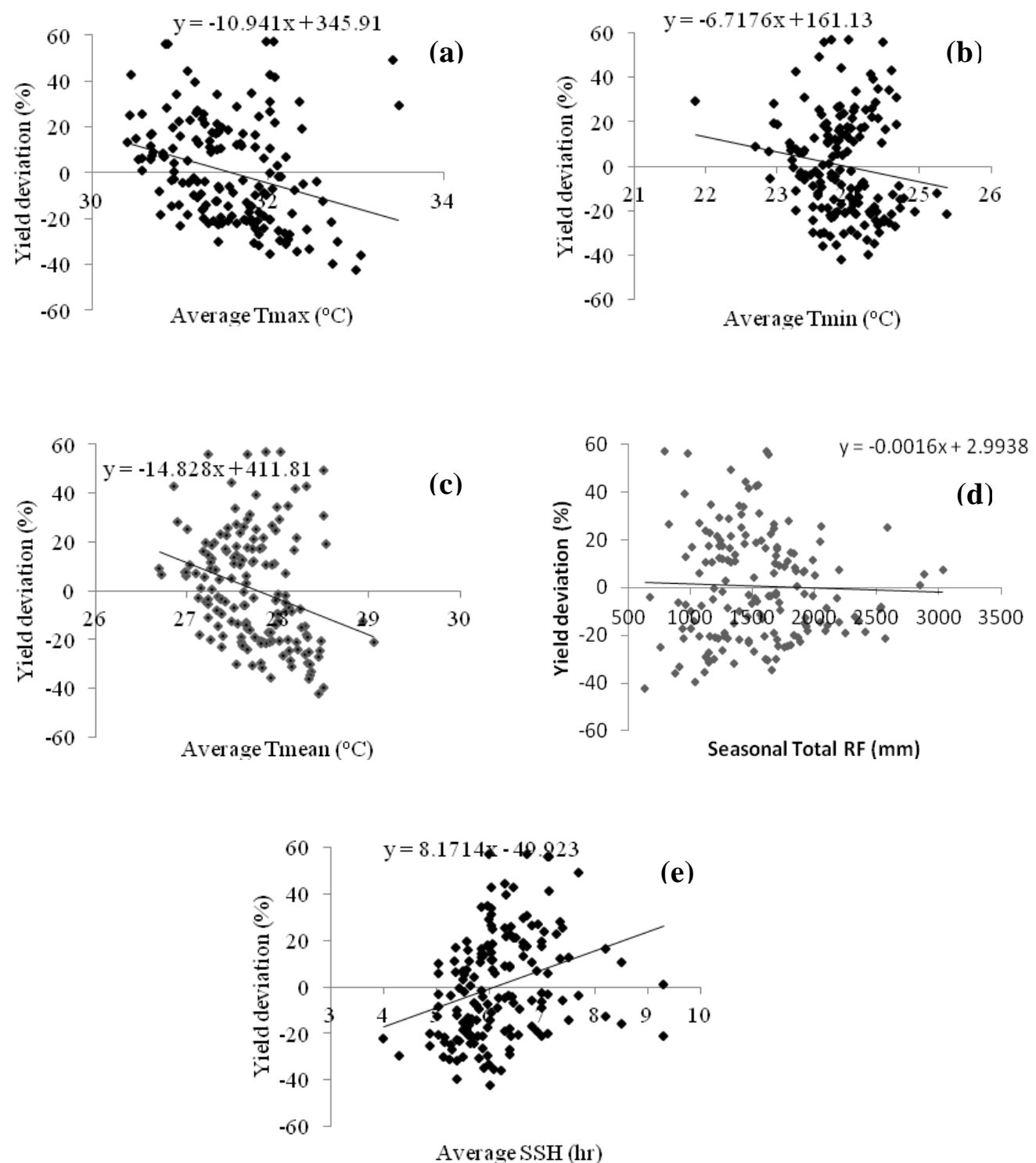

Figure 4. Relationship of percent deviation in T. Aman rice yield with seasonal (a) maximum, (b) minimum and (c) mean temperatures, (d) total rainfall and (e) avrerage sunshine hours in north-west region of Bangladesh 


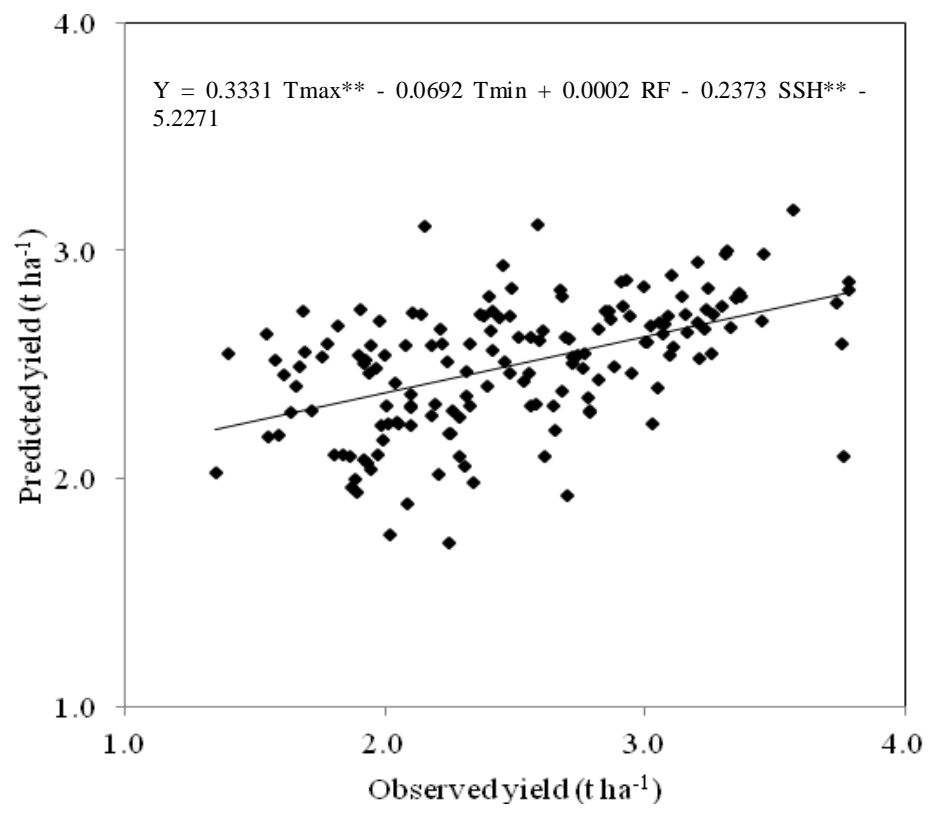

Figure 5. Multiple regression of maximum (Tmax) and minimum (Tmin) temperatures, total rainfall (RF) and sunshine hours (SSH) on T. Aman rice yield in north-west region of Bangladesh

\section{Conclusions}

The trend line analyses were done based on annual and seasonal climatic variables following MAKESENS model. Historical weather data of north-west parts of Bangladesh showed interannual and inter-seasonal variabilities. This indicates that climate change occurred in terms of increased temperatures, rainfall and reduction in sunshine hours. Increase in minimum temperature and decrease in sunshine hours are likely to reduce $T$. Aman rice yields in northwest part of Bangladesh. The study clearly indicates the usefulness of the regression based approach for evaluating the impact of climatic variability through yield of $T$. Aman rice. However, to make the characterization more realistic, there is a need to include other unaddressed biotic and abiotic factors in future, where simulation models could play an important role.

\section{Acknowledgement}

The authors acknowledge the Modeling Climate Change on Agriculture Project (CRP-II, KGF) for funding this study. This finding is the outcome of the collaborative research of BRRI, BARI and BSMRAU. We also acknowledge Dr. Motoki Nishimori of the National Institute of Agro-Environment Sciences and Dr. Jun Furuya, Social Science Division, Japan International Research Center for proving the data.

\section{References}

Agrawala, S., Ota, T., Ahmed, A. U., Smith, J. and van Aalst, M. 2003. Development and Climate Change in Bangladesh: Focus on Coastal Flooding and the Sunderbans. Organisation for Economic Co-operation and Development (OECD), Paris. 
Almaraz, J. J., Mabood, F., Zhou, X., Gregorich, E. G. and Smith, D. L. 2008. Climate change, weather variability and corn yield at a higher latitude location: Southwestern Quebec. Climate Change, 88:187197.

BBS (Bangladesh Bureau of Statistics), 2016. Yearbook of Agricultural Statistics-2014, Ministry of Planning. Government of the People Republic of Bangladesh, Dhaka, $390 \mathrm{p}$.

BBS (Bangladesh Bureau of Statistics). 2013. Yearbook of Agricultural Statistics-2011. Ministry of Planning. Government of the People Republic of Bangladesh, Dhaka, $370 \mathrm{p}$.

Hasan, A. B. M. S. and Rahman, M. Z. 2013. Change in temperature over Bangladesh associated with degrees of global warming. Asian Journal of Applied Science and Engineering, 2(2):62-75.

Hirsch, R. M., Alexander, R. B. and Smith, R. A. 1991. Selection of methods for the detection and estimation of trends in water quality. Water Resources Research, 27: 803-813.

Hussain, S. G. 2011. Assessing impact of climate change on cereal production and food security in Bangladesh. In Lal, R., Sivakumar, M. V. K., Faiz, S. M. A., Rahman, A. H. M. M. and Islam, K. R. (eds.) Climate Change and Food Security in South Asia. Springer Science+Business Media (www.springer.com). DOI 10.1007/978-90-481-9516-9 B. V. 2011, 459-476 pp.

IPCC (Intergovernmental Panel on Climate Change). 2013. Climate Change 2013: The Physical Science Basis: Summary for Policymakers. Contribution of the Working Group I to the Fifth Assessment Report of the Intergovernmental Panel on Climate Change. Cambridge University Press, Cambridge, United Kingdom and New York, USA, 1535 p.
Kalra, N., Chakraborty, D., Sahoo., R. N., Sehgal, V. K. and Singh, M. 2006. For assessing yields under extreme climatic events using crop simulation models: Aerosol layer effects on growth and yield of wheat, rice and sugarcane. In: Agriculture and Hydrology Applications of Remote Sensing, (ed.). R.J. Kuligowski, J.S.Parihar, and S. Genya, Proceedings of SPIE Vol. 6411-58.

Karmakar, S. and Shrestha, M. L. 2000. Recent climate change in Bangladesh. SMRC Bulletin No. 4. SMRC, Dhaka.

Kendall M.G., 1975. Rank Correlation Methods; Griffin: London, UK.

Mabe, F. N., Sarpong, D. B. and Osei-Asare, Y. 2014. Empirical evidence of climate change: Effects on rice production in the Northern region of Ghana. British Journal of Economic Management \& Trade, 4(4):551-562.

Maniruzzaman, M. and Biswas, J. C., 2014. Climatic variability and climate change: Wet season rice production in Rajshahi and Barisal regions of Bangladesh. In: Climate change and adaptation: Crop production in drought and saline prone areas of Banglades, (eds.) J.C. Biswas and $\mathrm{M}$ Maniruzzaman, Climate change and rice project, BRRI, Gazipur, 182p.

Maniruzzaman, M., Muttaleb, M. A., Choudhury, A. K., Akhter, S., Ahmed, F., Aziz, M. A., Rahman, M. M., Miah, M. M., Biswas, J. C., Hamid, M. A. and Kalra, N. 2017. Characterization of intereseasonal climate variability through dryseason rice productivity in the north-west region of Bangladesh. Italian Journal of Agrometerology, 1: 5-18.

Mann, H. B. 1945. Nonparametric tests against trend. Econometric, 13:245-259.

MoEF (Ministry of Environment and Forest). 2009. Bangladesh Climate Change 
Strategy and Action plan [Report], Ministry of Environment and Forest.

Mondal, M. S. and Wasimi, S. A. 2004. Impact of climate change on dry season water demand in the Ganges Delta of Bangladesh. In: Contemporary Environmental Challenges, (eds.) M.M. Rahman, M.J. B. Alam, M.A. Ali, M. Ali and K. Vairavamoorthy, Loughborough University, UK, 63-83 pp.

Peng, S., Huang, J., Sheehy, J. E., Laza, R. E., Visperas, R. M., Zhong, X., Centeno, G. S., Khush, G. S. and Cassman, K. G. 2004. Rice yields decline with higher night temperature from global warming. Proc. of the National Academy of Science. USA, 101:9971-9975.

Rahman, A. and Alam, M. 2003. Mainstreaming adaptation to climate change in Least Developed Countries (LDCs), Working Paper 2: Bangladesh Country Case Study, IIED, London, UK.

Rahman, M. R., Salehin, M. and Matsumoto, J. 1997. Trend of monsoon rainfall pattern in Bangladesh, Bangladesh Journal of Water Resource Research, 14-18:121-138.

Rani, B. A. and Maragatham, N. 2013. Effect of elevated temperature on rice phenology and yield. Indian Journal of Science and Technology, 6(8):5095-5097.

Shah, S. K., Ali, M. S. and Shahid, S. 2013. Development of Four Decade Long Climate Scenario \& Trend: Temperature, Rainfall, Sunshine \& Humidity. CDMP-II, Dhaka.
Shahid, S. 2008. Spatial and temporal characteristics of droughts in the western part of Bangladesh. Hydrological Process, 22:2235-2247.

Shahid, S. 2010. Recent trends in the climate of Bangladesh. Climate Research, 42:185193.

Shahid, S. 2011. Impact of climate change on irrigation water demand of dry season Boro rice in northwest Bangladesh. Climate change, 105:433-453.

Shi, Q., Zeng, X., Li, M., Tan, X. and Xu, F. 2002. Effects of different water management practices on rice growth. In: Water-Wise Rice Production, (eds.) Bouman, B.A.M., Hengsdijk, H., Hardy, B., Bindraban, P.S., Tuong, T.P. and Ladha, J.K., International Rice Research Institute, Manila. 3-13 pp.

Singh, K. K. and Kalra, N. 2016. Simulating impact of climatic variability and extreme climatic events on crop production. Mausam, 67(1):113-130.

Timsina, J., Wolf, J., Guilpart, N., van Bussel, L. G. J., Grassini, P., van Wart, J., Hossain, A., Rashid, A., Islam, S. and van Ittersum, M. K. 2016. Can Bangladesh produce enough cereals to meet future demand? Agricultural Systems (2016), http://dxdoi.org/10.1016/j.agsy.2016.1100 3. 